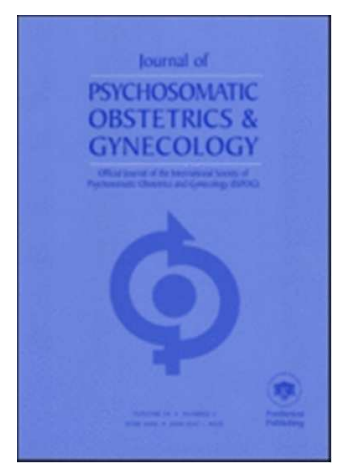

\title{
Approaches to the prevention of postnatal depression and anxiety - a review of the literature
}

\begin{tabular}{|r|l|}
\hline Journal: & Journal of Psychosomatic Obstetrics \& Gynecology \\
\hline Manuscript ID & DPOG-2017-0089.R2 \\
\hline Manuscript Type: & Review Paper \\
\hline Keywords: & prevention, postnatal depression, RCT, intervention, psychological \\
\hline \multicolumn{2}{|c}{} \\
\hline
\end{tabular}

\section{SCHOLARONE"}

Manuscripts 


\section{Searches}

Figure 1 : PRISMA flow diagram depicting the screening and selection process

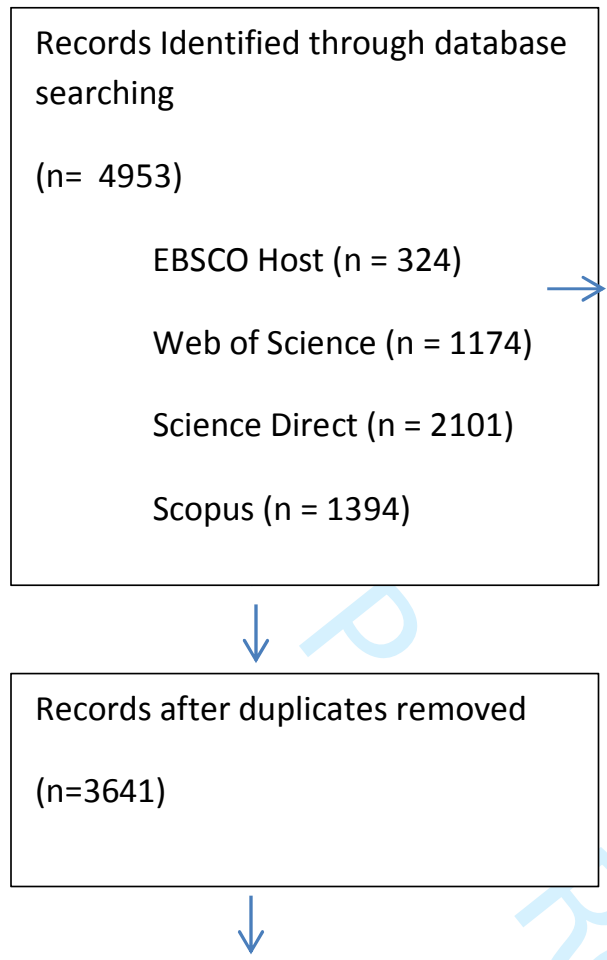

Records Included after screening titles

$(n=115)$

Records excluded by title screening for not meeting eligibility criteria $(n=3501)$
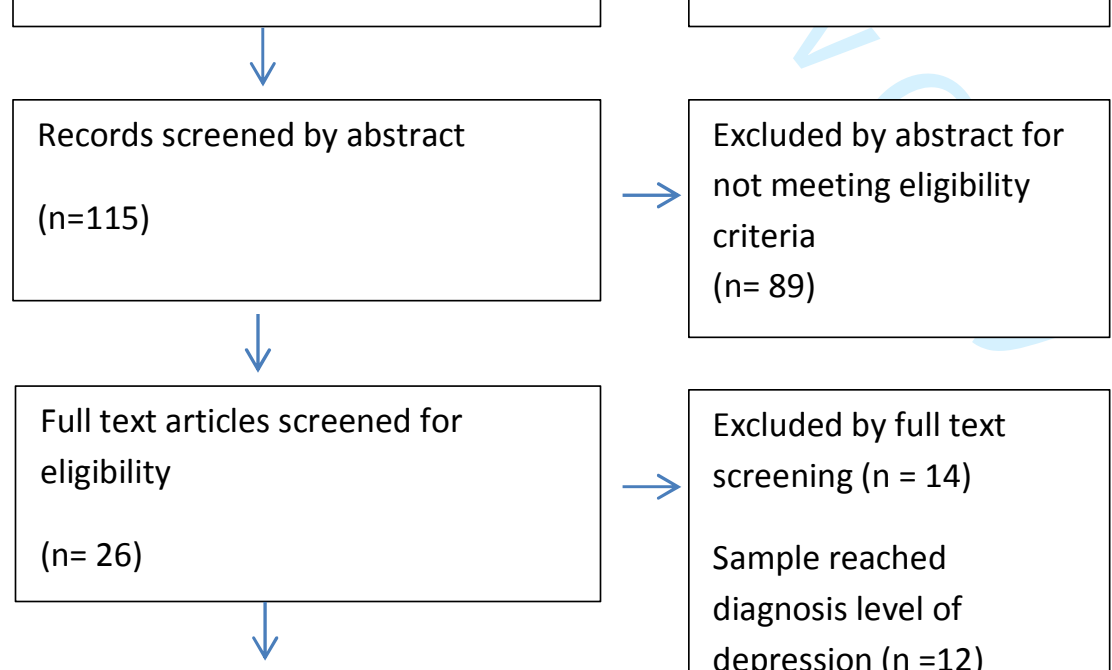

$\rightarrow$\begin{tabular}{|l|}
\hline Excluded by full text \\
screening $(n=14)$ \\
Sample reached \\
diagnosis level of \\
depression $(n=12)$ \\
Full text not available in \\
English $(n=1)$ \\
Non- RCT design $(n=1)$
\end{tabular}

Number of studies included $(n=12)$

Non- RCT desion $(\mathrm{n}=1)$ 


\begin{tabular}{|c|c|c|c|c|c|c|c|}
\hline \multicolumn{8}{|c|}{ Antenatal interventions } \\
\hline Author & $\mathbf{N}$ & $\begin{array}{l}\text { Inclusion/Exclusi } \\
\text { on }\end{array}$ & Intervention & Control & Measures & Findings and discussion & $\begin{array}{l}\text { Risk of } \\
\text { bias }\end{array}$ \\
\hline $\begin{array}{l}\text { Anton \& } \\
\text { David } \\
2015 \\
\text { Romania }\end{array}$ & $\begin{array}{l}\mathrm{N}=50 \\
\text { Control } \\
\mathrm{n}=25 \\
\text { Int } \\
\mathrm{n}=25\end{array}$ & $\begin{array}{l}\text { Inc: Not discussed } \\
\text { Excl: Previous } \\
\text { mental health } \\
\text { disorder or } \\
\text { psychotherapy }\end{array}$ & $\begin{array}{l}9 \text { weeks REBT } \\
\text { sessions, } 90 \\
\text { minutes each. }\end{array}$ & Usual care. & $\begin{array}{l}\text { POMS-S, BDI,STAI } \\
\text { Time 1: pre-test } \\
\text { Time 2: } 5 \text { weeks } \\
\text { Time 3: } 9 \text { weeks } \\
\text { Time 4: } 3 \text { months postnatal. }\end{array}$ & $\begin{array}{l}\text { No sig. difference between groups at T1 or T2, but sig. difference at T3 } \\
\text { for depression ( } p=0.022) \text { anxiety }(p=0.012) \text { and negative emotionality } \\
(p=0.019) \text {, although effect size small for depression }(d=.16) \text {. Within } \\
\text { group: Sig. difference found between T1 and T2 for intervention group } \\
\text { for depression ( } p=0.00) \text { anxiety }(p=0.001) \text { and negative emotionality } \\
(p=0.001) . T 4-\text { Depression no longer significant }(p=0.254)\end{array}$ & Low \\
\hline $\begin{array}{l}\text { Barrera, } \\
\text { Wickham \& } \\
\text { Munoz. } \\
2015 \\
\text { USA }\end{array}$ & $\begin{array}{l}\mathrm{N}=113 \\
\text { Control } \\
\mathrm{n}=54 \\
\mathrm{Int} \\
\mathrm{n}=57\end{array}$ & $\begin{array}{l}\text { Inc: Pregnant, }>18 \\
\text { years old. Excl: } \\
\text { Current diagnosis } \\
\text { MDE. }\end{array}$ & $\begin{array}{l}8 \text { Lessons based on } \\
\text { attachment theory, } \\
\text { social learning } \\
\text { theory. }\end{array}$ & $\begin{array}{l}\text { Information } \\
\text { only control- } 4 \\
\text { page leaflet on } \\
\text { PPD. }\end{array}$ & $\begin{array}{l}\text { Baseline - Demographics, CES-D, } \\
\text { MDES. } \\
\text { EPDS. Monthly from recruitment } \\
\text { to } 6 \text { months PN. }\end{array}$ & $\begin{array}{l}\text { No sig. differences between groups at baseline. } \\
\text { No sig. reduction in PPD found in e-MB vs information only ( } p=0.061) \text {. } \\
\text { Suggests e-MB more useful for those with high prenatal CES-D, as } \\
\text { each unit increase on prenatal CES-D resulted in } 8.9 \% \text { increase in } \\
\text { reported EPDS }>10(p=<0.01) \\
\text { Large drop out ( } n=852 \text { randomised, } n=111 \text { completed data). }\end{array}$ & Low \\
\hline $\begin{array}{l}\text { Kenyon et al } \\
2016 \\
\text { UK }\end{array}$ & $\begin{array}{l}\mathrm{N}=1213 \\
\text { Control } \\
\mathrm{n}=613 \\
\text { Int. } \\
\mathrm{n}=600\end{array}$ & $\begin{array}{l}\text { Inc: Primiparous } \\
>28 \text { weeks } \\
\text { gestation, with } \\
\text { social risk factors. } \\
\text { Excl: }<16 \text { years } \\
\text { old, recruited to } \\
\text { the FNP. }\end{array}$ & $\begin{array}{l}\text { Pregnancy } \\
\text { Outreach Work- } \\
\text { individualised } \\
\text { support from } \\
\text { randomisation to } 6 \\
\text { weeks PN. }\end{array}$ & Usual care & $\begin{array}{l}\text { Primary: service engagement, } \\
\text { EPDS } \\
\text { Secondary: Birth outcomes, self- } \\
\text { efficacy and bonding, infant } \\
\text { outcomes }\end{array}$ & $\begin{array}{l}\text { No sig. difference between groups for antenatal engagement or EPDS } \\
\text { (Mean difference }-0.59 \text { ( } 95 \% \mathrm{Cl}-1.24 \text { to } 0.06) .2 \text { or more social risk } \\
\text { factors -sig. reduction in mean EPDS ( } p=0.05 \text { ). No differences in } \\
\text { maternal/ neonatal birth outcomes. Significant improvement in } \\
\text { maternal-infant bonding for intervention group ( } p=0.05 \text { ). No significant } \\
\text { differences in long term neonatal outcomes between groups. }\end{array}$ & Low \\
\hline $\begin{array}{l}\text { Moshki et al } \\
2013 \\
\text { Iran }\end{array}$ & $\begin{array}{l}\mathrm{N}=330 \\
\text { Control } \\
\mathrm{n}=115 \\
\text { Int. } \\
\mathrm{n}=115\end{array}$ & $\begin{array}{l}\text { Inc: } 28-30 \text { weeks } \\
\text { gestation, no } \\
\text { history of anxiety } \\
\text { or depression, } \\
\text { lives in local area, } \\
\text { healthy fetus. }\end{array}$ & $\begin{array}{l}\text { Education } \\
\text { programme - } 3 \\
\text { workshops, } 3 \\
\text { subgroups. } \\
\text { Included emphasis } \\
\text { on HLOC. }\end{array}$ & Usual care & $\begin{array}{l}\text { Time 1: Baseline Demographics, } \\
\text { MHLCS } \\
\text { Time 2 : post-test - MHLCS } \\
\text { Time 3: } 4 \text { weeks postnatal - EPDS }\end{array}$ & $\begin{array}{l}\text { Significant increase in internal belief and sig. reduction in chance } \\
\text { belief post intervention. No significant change for control group. } \\
\text { Significant difference in depression scores for intervention vs control } \\
\text { ( } p=0.001) \text {. No antenatal measure of depression undertaken - cannot } \\
\text { attribute change to intervention alone. }\end{array}$ & Unclear \\
\hline $\begin{array}{l}\text { Mohammadi } \\
\text { et al } \\
2015 \\
\text { Iran }\end{array}$ & $\begin{array}{l}\mathrm{N}=127 \\
\text { Group 1 } \\
\mathrm{n}=43 \\
\text { Group 2 } \\
\mathrm{n}=42 \\
\text { Control } \\
\mathrm{n}=42\end{array}$ & $\begin{array}{l}\text { Inc: } 26-32 \text { weeks } \\
\text { gestation, EPDS } \\
<15, \text { no } \\
\text { complications, } \\
\text { not exercising } \\
\text { regularly. }\end{array}$ & $\begin{array}{l}\text { Group 1: } 40 \text { min } \\
\text { education session. } \\
\text { Group 2: same as 1, } \\
\text { plus exercise - } 2 \\
\text { months postnatal. }\end{array}$ & $\begin{array}{l}1 \text { non exercise } \\
\text { related AN and } \\
\text { PN education } \\
\text { session. }\end{array}$ & $\begin{array}{l}\text { Baseline- EPDS, FIF. } \\
\text { Time } 2 \text { - } 1 \text { month postnatal EPDS } \\
\text { \& FIF } \\
\text { Time } 3 \text { - } 2 \text { month postnatal EPDS } \\
\text { \& FIF }\end{array}$ & $\begin{array}{l}\text { Intention to Treat analysis. No significant difference found for any } \\
\text { group for any measure. Between groups EPDS scores not significant at } \\
\text { T2 ( } p=0.82 \text { ) or T3 ( } p=0.70) \text {. Most participants across both intervention } \\
\text { groups did not take part in regular exercise. No further qualitative } \\
\text { data addressing why many did not adhere to the intervention. }\end{array}$ & Unclear \\
\hline
\end{tabular}

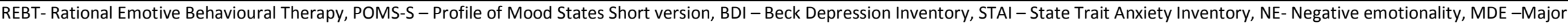

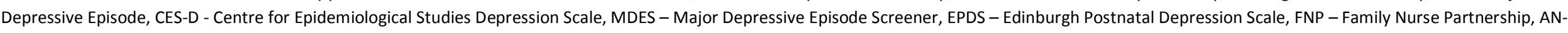
Antenatal PN - Postnatal, HLOC - Health Locus of control, FIF - Fatigue Identification Form, MHLCS - Multidimensional Health Locus of Control scale

\section{Table 1. Table of characteristics for studies using antenatal interventions}




\begin{tabular}{|c|c|c|c|c|c|c|c|}
\hline \multicolumn{8}{|c|}{ Postnatal interventions } \\
\hline Author & $\mathbf{N}$ & Inclusion/Exclusion & Intervention & Control Group & Measures & Analysis & $\begin{array}{l}\text { Risk of } \\
\text { bias }\end{array}$ \\
\hline $\begin{array}{l}\text { Ayers, } \\
\text { Fitzgerald, \& } \\
\text { Thompson. } \\
2015 \\
\text { UK }\end{array}$ & $\begin{array}{l}\mathrm{N}=80 \\
\text { Control } \\
\mathrm{n}=40 \\
\text { Int. } \\
\mathrm{n}=40\end{array}$ & $\begin{array}{l}\text { Inc: Fluent in } \\
\text { English, }<18 \text { years, } \\
>18 \text { months } \\
\text { postnatal. }\end{array}$ & $\begin{array}{l}\text { Brief online self- } \\
\text { help - CBT to } \\
\text { improve self- } \\
\text { esteem, mood, } \\
\text { positive self- } \\
\text { perceptions, } \\
\text { challenge negative } \\
\text { beliefs. }\end{array}$ & $\begin{array}{l}\text { Active - self-help } \\
\text { time } \\
\text { management } \\
\text { exercise }\end{array}$ & $\begin{array}{l}\text { Time } 1 \text { (T1) - Pre-test. } \\
\text { HADS, UMACL, SES, demographic } \\
\text { information, } \\
\text { Time } 2 \text { (T2) -Post-test } \\
\text { HADS, UMACL, SES, acceptability } \\
\text { information. }\end{array}$ & $\begin{array}{l}\text { Significant interaction between condition and time }(p=.001) \text { for both } \\
\text { groups. Mood change over time significant across both groups ( } p \\
<.001) \text {. Greater difference in mean values in intervention group. } \\
\text { Feedback on acceptability generally positive for both groups ( } 89.7 \% \\
\text { Intervention vs } 64 \% \text { control) Negative comments included } \\
\text { intervention better for women with mild to moderate depression, but } \\
\text { not for severe cases. }\end{array}$ & Low \\
\hline $\begin{array}{l}\text { Di Blasio et } \\
\text { al } \\
2015 \\
\text { Italy }\end{array}$ & $\begin{array}{l}\mathrm{N}=176 \\
\begin{array}{l}\text { Control } \\
\mathrm{n}=89\end{array} \\
\text { Int. } \\
\mathrm{n}=89\end{array}$ & $\begin{array}{l}\text { Inclusion: Italian } \\
\text { speaking, no } \\
\text { medical history of } \\
\text { psychiatric } \\
\text { diagnosis, }>17 \text { years } \\
\text { old. }\end{array}$ & $\begin{array}{l}\text { Making Sense } \\
\text { writing task at } 72 \\
\text { hours postnatal- } \\
\text { about childbirth } \\
\text { thoughts and } \\
\text { emotions, once } \\
\text { for } 20 \text { minutes }\end{array}$ & $\begin{array}{l}\text { Control - Writing } \\
\text { about daily tasks } \\
\text { and behaviours, } \\
72 \text { hours } \\
\text { postnatal }\end{array}$ & $\begin{array}{l}\text { T1 - } 32-40 \text { weeks gestation - } \\
\text { demographic questions, BDI, } \\
\text { LASC. } \\
\text { T2 - } 96 \text { hours postnatal - BDI and } \\
\text { PPQ. } \\
\text { T3 - } 3 \text { months Postnatal - BDI and } \\
\text { PPQ }\end{array}$ & $\begin{array}{l}\text { For Depression: At T2 - greater reduction in depressive symptoms for } \\
\text { intervention than control. } \\
\text { At T3 - reduced depressive symptoms intervention group, stable } \\
\text { results control. } \\
\text { Intervention: predictive effect T2, moderating effect T3. } \\
\text { For PTSD: No significant difference in between groups at T2. Sig. } \\
\text { difference between groups at T1 and T3 (Sig. decrease in intervention } \\
\text { group, increase in control group). Intervention - significant moderating } \\
\text { effect only at T3. }\end{array}$ & Unclear \\
\hline $\begin{array}{l}\text { Fisher et al } \\
2016 \\
\text { Australia }\end{array}$ & $\begin{array}{l}\mathrm{N}=400 \\
\text { Int. } \\
\mathrm{n}=204 \\
\text { Control } \\
\mathrm{n}=196\end{array}$ & $\begin{array}{l}\text { Inc: primparous, }<6 \\
\text { weeks postnatal, } \\
\text { Receiving care at } \\
\text { selected health } \\
\text { centres } \\
\text { Exclusion: } \\
\text { insufficient English, } \\
\text { multiparity }\end{array}$ & $\begin{array}{l}\text { Psychoeducational } \\
\text { package delivered } \\
\text { by trained nurses. } \\
\text { Received printed } \\
\text { materials. } \\
\text { Optional } 6 \text { hour } \\
\text { seminar offered at } \\
6-8 \text { weeks PN. }\end{array}$ & $\begin{array}{l}\text { Treatment as } \\
\text { usual }\end{array}$ & $\begin{array}{l}\text { T1: } 6 \text { weeks PN - PHQ-9, PHQ } \\
\text { GAD 7, PHQ PD, general health, } \\
\text { demographic information, VPSQ, } \\
\text { IBM. } \\
\text { T2: } 6 \text { months PN - CIDI , PHQ 9, } \\
\text { PHQ GAD 7, PHQ PD, Feeding, } \\
\text { PAQ, Infant sleeping. }\end{array}$ & $\begin{array}{l}\text { No significant differences in rate of diagnosis of PCMD between } \\
\text { groups. No sig. difference in depressive symptoms between groups, } \\
\text { no sig. difference in intimate relationship satisfaction between groups. } \\
\text { Reduced prevalence of mild to moderate anxiety symptoms and } \\
\text { better self-rated health for the intervention group. } \\
\text { Optional seminars (undertaken by } 94 \text { of the intervention group) was } \\
\text { found to be helpful, salient and easy to understand by }>85 \% \text { of the } \\
\text { sample. }\end{array}$ & Low \\
\hline $\begin{array}{l}\text { Gao et al } \\
2015 \\
\text { China }\end{array}$ & $\begin{array}{l}\mathrm{N}=180 \\
\text { Control } \\
\mathrm{n}=90 \\
\text { Int. } \\
\mathrm{n}=90\end{array}$ & $\begin{array}{l}\text { Inclusion: } \\
\text { Primiparous, term } \\
\text { baby, married. } \\
\text { Exclusion: postnatal } \\
\text { complications, } \\
\text { history of } \\
\text { psychiatric illness. }\end{array}$ & $\begin{array}{l}\text { Leaflet on sources } \\
\text { of assistance for } \\
\text { PN women, plus } 1 \\
\text { hour IPT } \\
\text { education session } \\
\text { before discharge. } \\
\text { Follow up call } \\
\text { after } 2 \text { weeks. }\end{array}$ & $\begin{array}{l}\text { Brief visit from a } \\
\text { nurse in the PN } \\
\text { ward to give } \\
\text { them a leaflet on } \\
\text { sources of } \\
\text { assistance for PN } \\
\text { women. }\end{array}$ & $\begin{array}{l}\text { Pre- randomisation } 2-3 \text { days PN- } \\
\text { Demographic question, EPDS, } \\
\text { PSSS, PSCS-E } \\
6 \text { weeks PN: EPDS, PSSS, PSCS-E } \\
\text { at the postnatal care clinic }\end{array}$ & $\begin{array}{l}\text { Significantly lower EPDS scores in intervention than control }(p=<.001) \\
\text { at } 6 \text { weeks postnatal. } \\
6 \text { weeks PP, higher levels social support }(p=.009) \text { \& maternal role } \\
\text { competency }(p=<.001) \text { for intervention than control. Significant } \\
\text { differences shown between groups for all outcomes. No significant } \\
\text { differences in the change between scores at T1 and T2. }\end{array}$ & Low \\
\hline $\begin{array}{l}\text { Howell } \\
\text { et al } \\
2013 \\
\text { USA }\end{array}$ & \begin{tabular}{|l|}
$\mathrm{N}=540$ \\
Int. \\
$\mathrm{N}=270$ \\
Control \\
$\mathrm{n}=270$
\end{tabular} & $\begin{array}{l}\text { Inclusion: Caucasian } \\
\text { or Asian women, } \\
>18 \text { years, babies } \\
\text { BW }>2.5 \mathrm{~kg}, 5 \\
\text { minute Apgar } \\
\text { scores } \geq 7 \text {. }\end{array}$ & $\begin{array}{l}\text { Intervention } \\
\text { group - } 2 \text { step } \\
\text { educational } \\
\text { intervention }\end{array}$ & $\begin{array}{l}\text { Usual PN care } \\
\text { plus list of health } \\
\text { related } \\
\text { community } \\
\text { resources. }\end{array}$ & $\begin{array}{l}\text { 1-3 days PN: Sociodemographic } \\
\text { health, anxiety, social support, } \\
\text { EPDS and PHQ-9. } \\
3 \text { weeks, } 3 \text { months and } 6 \text { months } \\
\text { PN: EPDS, PHQ9. }\end{array}$ & $\begin{array}{l}\text { No difference in positive depression screens for intervention versus } \\
\text { control at any time (OR 0.97; } 95 \% \mathrm{Cl} 0.59-1.61 \text { ) } \\
\text { Change over time - no difference in depressive symptoms for } \\
\text { intervention and control. No significant differences in depressive } \\
\text { symptoms between intervention and control groups. }\end{array}$ & Low \\
\hline
\end{tabular}




\begin{tabular}{|c|c|c|c|c|c|}
\hline $\begin{array}{l}\text { Lewis et al } \\
2013 \\
\text { USA }\end{array}$ & $\begin{array}{l}\mathrm{N}=130 \\
\text { Int. } \\
\mathrm{n}=66 \\
\text { Control } \\
\mathrm{n}=63\end{array}$ & $\begin{array}{l}\text { Incl: }<8 \text { weeks } \\
\text { postnatal, history of } \\
\text { depression (not } \\
\text { current). } \\
\text { Excl: no English, } \\
\text { health condition } \\
\text { which would } \\
\text { prevent exercise. }\end{array}$ & $\begin{array}{l}\text { Postnatal Physical } \\
\text { Activity: } 11 \text { phone } \\
\text { sessions over } 6 \\
\text { months. Aim to do } \\
\text { physical activity } \\
30 \text { minutes, } 5 \text { days } \\
\text { per week. }\end{array}$ & $\begin{array}{l}\text { Support control } \\
\text { condition - by } \\
\text { phone over } 6 \\
\text { months, similar } \\
\text { contact to } \\
\text { intervention. } \\
\text { Discussed } \\
\text { wellness topics. } \\
\end{array}$ & $\begin{array}{l}\text { T1 - baseline } \\
\text { PHQ- } 9 \\
\text { PSS } \\
\text { PSQI } \\
\text { T2 - } 6 \text { months Structured Clinical } \\
\text { Interview for DSM- IV Axis I } \\
\text { Disorders PHQ-9, EPDS, PSS, } \\
\text { PSQI. 7-day PAR interview. } \\
\end{array}$ \\
\hline $\begin{array}{l}\text { Perez-Blasco, } \\
\text { Viguer, \& } \\
\text { Rodrigo. } \\
2013 \\
\text { Spain }\end{array}$ & $\begin{array}{l}\mathrm{N}=26 \\
\text { Int. } \\
\mathrm{n}=13 \\
\text { Control } \\
\mathrm{n}=13\end{array}$ & $\begin{array}{l}\text { Inclusion: } \\
\text { Breastfeeding } \\
\text { mothers. }\end{array}$ & $\begin{array}{l}8 \text { week } \\
\text { programme, } 2 \\
\text { hours per week. } \\
\text { Programme based } \\
\text { on MBSR, MBCT } \\
\text { and Mindful Self- } \\
\text { compassion. }\end{array}$ & $\begin{array}{l}\text { No intervention, } \\
\text { but } 2 \text { sessions of } \\
\text { mindfulness } \\
\text { offered after } \\
\text { post-test } \\
\text { measures. }\end{array}$ & $\begin{array}{l}\text { Time 1- Baseline. } \\
\text { Demographics, EEP, FFMQ, SCS- } \\
\text { SF, DASS-21, SWLS, Subjective } \\
\text { happiness scale. } \\
\text { Time } 2 \text { - } 3 \text { weeks post-test - } \\
\text { measures repeated (except } \\
\text { demographics) }\end{array}$ \\
\hline
\end{tabular}

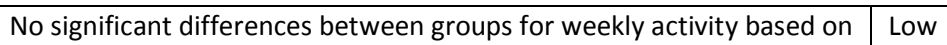
PAR. Intervention lower depressive scores on EPDS than control ( $p=0.001$ ), no significant difference for PSS

$29 \%$ of sample using antidepressants at baseline, $30 \%$ at 6 months. Differences in antidepressant use between times not significant for either group. 10 participants ( 5 from each group) reached diagnosis of depression at 6 months on SCID-I, no difference between groups on Fisher Exact Test $p=1.00$.

No significant difference between groups at baseline. Significant difference for intervention group at T2 for anxiety, stress,

psychological distress, FFMQ subscales for observing, acting with awareness, non-judging of inner experience and non-reactivity to inner experience. On SCS, intervention group significantly higher on self-kindness, mindfulness and total score, significantly less on overidentification subscale. Difference in satisfaction with life and subjective happiness in the expected direction but not significant.

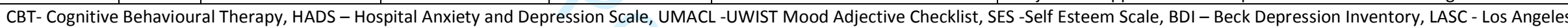

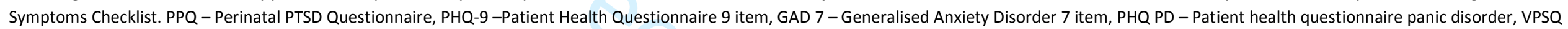

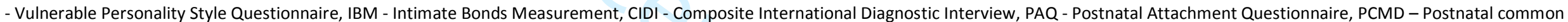

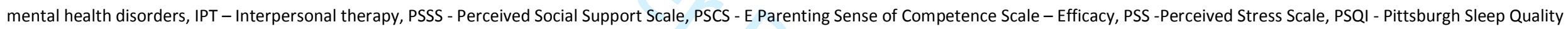

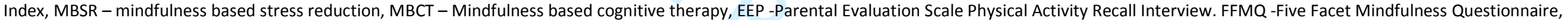
SCS- SF -Self-compassion scale, SWLS -Satisfaction with life scale.

\section{Table 2. Table of characteristics for studies using postnatal interventions}


1 Approaches to the prevention of postnatal depression and anxiety - a review of the

2 literature

\section{Abstract}

4 Introduction: Poor maternal mental health during the perinatal period has been shown to 5 have potentially long-lasting effects for mother and child. In recognition of this, maternal 6 mental health is receiving increased attention from political and healthcare organizations,

7 with a growing focus on preventing the onset of common mental health disorders.

8 Objective: The objective for this review is to provide an update of randomized controlled 9 trials examining the use of interventions targeted to prevent the onset of postnatal depression and anxiety in non-diagnostic populations with universal or selected samples.

Methods: A total of four databases, EBSCO Host, Science Direct, Scopus and Web of Science, incorporating PsychINFO were searched and papers selected according to clearly specified inclusion criteria. A large Health Technology review was published in 2016, for which the final search was conducted in December 2012.Therefore inclusion criteria were studies published from January 2013 onwards, available in English language, had a focus on prevention of postnatal maternal depression and anxiety, and used psychological interventions. Drug intervention trials were excluded.

Findings: 12 studies were identified as examining antenatal or postnatal intervention trials with an aim of preventing maternal postnatal depression and/or anxiety. There continues to be limited evidence to recommend specific prevention strategies for universal samples without further testing. There is evidence to suggest the use of rational-emotive behavioral therapy in an antenatal sample may have some utility, and the use of psychotherapy-based interventions in a postnatal setting is also supported although both require further investigation. Additionally, there is a need to gather information on acceptability, as many trials were hindered by poor adherence to interventions and high attrition that were otherwise unexplained.

Keywords: prevention, postnatal depression, RCT, psychological, intervention

\section{Current knowledge}

- Perinatal maternal mental health is important for women and the developing fetus

- The importance of maternal mental health is increasing on both health and political agendas worldwide.

- There is some evidence of the efficacy of psychosocial/ psychological interventions for the prevention of postnatal depression and anxiety.

\section{What this study adds}


- Recent additions to the literature do not add robust evidence of effectiveness of universal antenatal or postnatal prevention of postnatal distress

- There is evidence to support the use of Rational Emotive Behavioral Therapy in samples of women during the antenatal period. There is also evidence to support the use of psychotherapy based interventions in the postnatal setting, but both require additional investigation.

- There is a need for more detailed qualitative feedback on acceptability of interventions for women.

\section{Approaches to prevention of postnatal depression and anxiety - A review of the literature}

\section{Background}

Poor mental health during the perinatal period has the potential to cause lasting harm not only to the mother, but also to the wellbeing and development of the unborn child [1-5]. Literature suggests that between 10 and 20 percent of women will develop mental illness within the postnatal period [30], and within the UK $9 \%$ of postnatal maternal mortality is caused by mental health disorders [6]. Over the last 20 years the impact of maternal mental health has risen on both the worldwide political and healthcare agendas. At the turn of the millennium, the United Nations set 8 goals to be achieved by the year 2015 [7]. One such goal was titled "improving maternal health". During the course of the Millennium Development Goals period, a sub-goal for recognizing the importance of maternal mental health was released [8], which set out to reduce poor maternal mental health across the world by 2015 .

Within a national setting the UK government published the policy "No health without mental health" [9]. This set out guidelines for improving mental health, without specifically referring to maternal mental health. This was followed by the publication of the Department of Health policy document "Closing the Gap: Priorities for Essential Change in Mental Health" [10], which addressed the importance of good maternal mental health for the wellbeing of both mothers and children, and outlined a strategy to promote good mental health and the importance of prevention of common mental health disorders in the puerperium. As the experience of poor maternal mental health is associated with poor outcomes for both mother and child, prevention of the development of poor mental health is the most effective way to reduce this burden [29].In response to these, the Royal College of Gynecologists and Obstetricians (RCOG) published a good practice document outlining 
1 the management of women with perinatal mental health disorders. Within this, it was

2 highlighted that psychosocial (those using mental, physical or social approaches) and

3 community based interventions should be used where there is evidence of mild to moderate mental health problems, such as depression and anxiety [11]. Additionally, the National Institute for Health and Care Excellence (NICE) guidelines for antenatal and postnatal mental health also address the importance of discussing prevention techniques with women during the perinatal period [12].

In 2013, Dennis and Dowswell [13] published a Cochrane review of psychosocial and psychological interventions aiming to prevent postnatal depression (PND). After an examination of 28 relevant papers, involving a total of 17000 women, the authors concluded that there is good evidence to support the use of psychosocial and psychological interventions for prevention of PND, as those women who undertook interventions were significantly less likely to develop severe symptoms.

In 2016, Morrell et al [14] published a systematic review of the literature of interventions aiming to prevent the development of postnatal depression, looking at clinical effectiveness, cost effectiveness, safety and acceptability. The review described interventions across 3 different populations, those women of a 'universal' background, those with a more targeted population who were selected as they had social risk factors (selective), finally a third group who had significant levels of distress but not reaching full clinical diagnosis (indicated). 87 papers were reviewed across both quantitative and qualitative methodologies. The reviewers found that approaches varied, with interventions such as potential redesign of midwifery postnatal care, education packages, person-centered approach (PCA) and cognitive-behavioral approaches (CBA) for the universal populations. The redesign of midwifery postnatal care included midwifery care to be extended to three months postnatally, and to be both tailored to individual needs and flexible. The authors concluded that the reviewed trials appeared to be cost-effective when compared to usual care, but that the interventions warranted replication using large scale, randomized controlled trial study design in order to improve rigor. Additionally, the authors included a list of recommendations for future intervention and trial designs, including the need to address the importance of a continuous and trusting relationship with a care provider, with study 
1 sample sizes sufficient to achieve statistical power, and that additional qualitative

2 information is gathered about acceptability and women's perspectives of interventions.

3 Although there has been much investigation into prevention of PND, there is an increasing awareness of the high rate of anxiety disorders during the perinatal period with prevalence

5 estimates as high as $15.8 \%$ in pregnancy and $17.1 \%$ postnatally [28]. Although often linked,

6 research tends to focus primarily on symptoms of depression and neglects to explore the

7 improvement of other mental health problems in the perinatal population. Therefore, this

8 review also considers studies which address symptoms of anxiety.

\section{Aim}

The aim of the following review of the literature is to provide an update since the publication of the Morrell et al review (2016) [14] of trials of psychosocial interventions aiming to prevent the onset of postnatal depression or anxiety in populations with universal, indicated and selected samples, which do not meet the threshold for a current diagnosis of depression or anxiety using common mental health measures.

Inclusion and exclusion criteria

The review aims to provide an update to the literature search performed as part of the Morrell et al (2016) [14] review. Their final search was conducted in December 2012, therefore searches for the current review included papers published from January 2013 onwards. Searches were conducted using electronic databases EBSCO Host, Science Direct, Scopus and Web of Science, which covered most common databases for health and psychology literature including PsychINFO. Searches of the reference lists of identified studies were also undertaken. To meet the requirements for inclusion, studies had to meet the following criteria

1. Utilise a randomized controlled trial design

2. Implement a psychosocial intervention aiming to prevent the onset of antenatal or postnatal depression and/or anxiety 
3. Be implemented during pregnancy or the postnatal period, as specified by the authors, typically but not invariably to 12 months postpartum

4. Measure depression and/or anxiety symptoms using validated self-complete or clinician administered measures for depression and anxiety.

5. Involve participants who do not achieve diagnostic levels of depressive or anxiety symptoms at baseline, in order for the intervention to be considered preventative.

6. Be available in English language

7. Be published since the final search of the HTA review was completed (January 2013 onwards)

Studies of drugs and medicines were excluded as they are based on biological processes rather than psychosocial ones, on which this review is focused. Additionally, trials using nonhuman subjects are also excluded.

\section{Search terms and strategy} (postnatal* OR perinatal* OR postpartum OR Post-partum ) AND (prevent* OR reduc* OR improv* OR enhance* OR intervent*) AND (distress OR depress* OR stress OR wellbeing OR anxi*)

The search identified 4953 records for screening, of which 1312 were duplicates (See Figure 1). The remaining 3641 papers were screened for suitability, and from the title 115 papers were identified as potentially relevant. The large number of papers excluded by title alone included reference to drug trials, non-human participants, genetic research, and general medical research looking at the non-pregnant population. Evaluation of the abstracts identified 26 papers for closer consideration, of which 12 met all inclusion criteria upon reading in full.

\section{Searches}

[insert figure 1 here]

The 12 included papers have been grouped by the timing of the intervention, with five papers detailing studies into interventions undertaken in the antenatal period with the aim of preventing postnatal depression or anxiety, and a further seven studies detailing interventions in the postnatal period to prevent postnatal distress. Due to the differing 
1 outcome measures and time points for follow up in the included studies, it was not

2 considered suitable to conduct a meta-analysis.

3

4

5

6

7

8

9

10

11

12

13

14

15

16

17

18

19

20

21

22

23

24

25

26

27

28

29

30

31

32

33

34

35

36

37

38

39

\section{Risk of bias assessment}

A risk of bias evaluation was undertaken using the Cochrane risk of bias tool [31], used in order to remain consistent with the Morrell et al [14] review. Each study was assessed as low risk, high risk or unclear risk for selection bias, performance bias, detection bias, attrition bias, reporting bias and "other" bias (see Tables 1 and 2). A total of $66.6 \%$ of the studies (8/12) were assessed as low risk of selection bias, with the remaining $33.4 \%(4 / 12)$ assessed as unclear risk due to lack of information within reporting. For performance bias, 91.6\% (11/12) were assessed as low risk, with just one assessed as high risk due to the authors self-acknowledged lack of blinding [17] which may have impacted upon study findings. This also impacted on the judgment of detection bias for this trial, as lack of blinding also led to an assessment of high risk of bias in this category. Only $41 \%$ (5/12) were judged to be at low risk of detection bias and $50 \%$ (6/12) at unclear risk of detection bias, again due to lack of detail within reporting. All 12 studies were assessed to be at low risk of bias for attrition, reporting bias, and "other" biases.

\section{[Insert table 1 here]}

\section{[Insert table 2 here]}

\section{Antenatal Interventions for prevention of postnatal depression and/or anxiety}

The five papers outlining antenatal interventions (see Table 1) to prevent postnatal depression and/or anxiety were from a variety of countries and with a large range of sample size. Two were from Iran, one each from Romania, the UK and USA. There was a total of 1729 participants included across all five studies, but the largest proportion of participants were recruited in the UK trial undertaken by Kenyon et al (2016) [15] ( $N=1213$, Intervention group 600, Control group 613). The remaining studies used much smaller samples, with the studies in Iran recruiting 230 [16] and 127 participants [17] respectively. The study conducted in Romania recruited a total of only 48 participants [18] and the study undertaken in the USA recruited 111 women [19].

There were four different intervention strategies assessed. Two papers examined the effectiveness of education based interventions $[19,16]$ one looked at the impact of an exercise intervention on postnatal wellbeing [17] another considered peer support as a potential buffer for postnatal distress [15] and the final paper examined the effectiveness of rational-emotive behavioral therapy (REBT)[18]. 
Both Anton \& David (2015) [18] and Moshki et al (2014) [16] reported significant differences in the rate of depressive symptoms between control and intervention groups at post intervention (9 weeks and 4 weeks postnatal, respectively). Anton \& David (2015) [18] found that the use of REBT reduced symptoms of anxiety and depression over a 9-week period when measured using validated tools, as well as negative emotionality, although the effect for depressive symptoms was not maintained at three months. Moshki et al (2014) [16] also reported significant difference in post-test depression scores using the Edinburgh Postnatal Depression Scale for intervention and control groups when using an educational intervention on antenatal, intrapartum and postnatal changes, physiology and health, emotions and attitudes, which focused on health locus of control. However, there was no measure of depression symptoms taken at baseline, meaning it is not possible to conclude that the difference in scores is due to the intervention and was not present as a significant difference at recruitment.

Three of the included trials $[19,15,17]$ did not find significant improvements in depression scores postnatally following intervention use; however, there were significant improvements in two out of these three trials for subgroups of those with high levels of distress at baseline [19], or with two or more social risk factors [15]. Although, by definition, it is easier to demonstrate a greater change where initial rates are higher, this suggests that such interventions might have more utility with those of a "selected" sample, i.e. those with a higher number of risk factors or sub-diagnostic distress, rather than prevention in a universal sample. In these studies, examples of risk factors included non-English speakers, those requiring assistance with benefits or housing, or experiencing domestic abuse.

The three interventions completed in the antenatal period that reported no significant effect of postnatal depression scores were primarily completed online or via telephone, suggesting that the remote nature of the intervention may have an impact on efficacy when compared to interventions completed on a group or individual face to face basis.

Additionally, some trials demonstrated various difficulties in the study process, including low retention rates and poor intervention adherence. This suggests that the study process, intervention or both were of questionable acceptability to women. Barrera and Wickham (2015) [19] began with a sample of 852 women, and yet only 111 completed a full data set. This rate of attrition is substantial and suggestive of low acceptability for women. Although the feedback on feasibility gathered as part of the trial reported that the process and intervention were acceptable and useful, this drew only on a selected sample of women through only asking those who reached the final data point rather than asking those who did not complete data points why they did not engage. Mohammadi et al (2015) [17] found that for the antenatal exercise intervention groups (one for exercise throughout antenatal 
1 period, one for antenatal period and up to 2 months postnatal) neither group actually

2 participated in regular exercise.

3

4 In summary, there is limited evidence to recommend use of any of the examined 5 interventions without further testing. The findings suggest that use of REBT as a therapy for 6 prevention in a universal sample of women may be of some short-term benefit, but this 7 requires further exploration. Additionally, there is a need to gather data on acceptability of 8 interventions in all cases, and attempts should be made to gather data from those who do not engage with an intervention where possible. The use of intensive lay person support [15] in the antenatal period has some suggested benefit for those with identified social risk factors and there would be some merit in repeating this trial using a full selective sample of this kind in order to further investigate this finding. The effectiveness of an intervention with an indicated sample is also seen in Barrera and Wickham (2015) [19], as those in the intervention group with the highest rate of depression in the prenatal period had a significant reduction in postnatal depression when compared to the control group.

\section{Postnatal Interventions for prevention of postnatal distress}

Seven papers met the inclusion criteria and detailed interventions undertaken in the postnatal period to prevent postnatal distress (see Table 2). Of these, two were from the USA, one each from England, Australia, Italy, Spain, and China. There was a total of 1406 participants across these studies, with the largest samples from the USA (Howell et al 2014, $\mathrm{N}=540$ ) [20] and Australia (Fisher et al 2016, $\mathrm{N}=400$ ) studies [21]. The smallest sample size was 26 participants for the study conducted in Spain [22], followed by the English study with 80 participants [25]. The smaller American trial recruited a total of 130 women [23], with the Chinese trial recruiting 180 participants [24] and the Italian study 176 participants [26].

The studies were again varied in intervention type, with one trial focusing on the impact of an exercise based intervention [23] and four focusing on psychotherapy based interventions $[22,24,25,26]$. The remaining two trials examined the effectiveness of education interventions to prevent postnatal distress, with Fisher et al (2016) [21] focusing on a psycho-education package for couples, and the large scale USA trial looking at education surrounding behavior to improve outcomes [20].

Three of the included papers found no significant difference on primary outcome measures between intervention and control groups [20,21, and 23]. These trials examined the utility of a psycho-educational package, a two-step behavioral education intervention based on the common-sense model and a physical activity intervention respectively. 
1 perceives her body and might result in unrealistic expectations about what can be physically

2 accomplished. Failure to meet such expectations could then foster depressive symptoms

3 [20]. Howell et al's (2014) [20] intervention aimed to prime mothers to recognize, interpret

4 and normalize triggers of depressive symptoms (step one), and review an education

5 pamphlet with a trained social worker in hospital (step two). Participants also received a

6 two-week post-delivery phone call at which point the social worker assessed symptoms and

7 the woman's management of these. The use of a trained social worker in order to deliver

8 the intervention, may have affected how women engaged with the trial as social workers as

9 a profession are often linked with negative opinions and some hostility within a general

10 population [27]. However, there is clearly a more generic underpinning issue of perceived

11 utility or relevance of intervention and motivational issues perhaps need further 12 consideration.

13 The Fisher et al (2016) [21] paper shows that only a small number of the intervention group completed the full education package (involving information leaflets, additional care by a trained professional plus attendance at a seminar), meaning that the outcome data is not reflective of use of the full intervention pack. However, it is an evaluation of the provision of that care package. Additionally, Lewis et al (2014) [23] also reported that there was no significant difference in the amount of exercise between groups, making between group comparisons difficult. Both of these factors may go some way to providing an explanation as to why there are no significant differences between intervention and control in these studies.

Two trials reported statistically significant differences in mood or depression scores following self-help based interventions [25, 26]. A study by Ayers et al (2015) [25] aimed to encourage positive maternal mood. Women self-selected by following a link provided to them via various channels, but which could not be reached serendipitously. Eligibility was extended when compared to other RCTs, with women up to 18 months postnatal able to participate. The rationale given for such inclusion was the awareness that women may continue to experience negative mood beyond 12 months postpartum, and to maximize potential recruitment numbers. However, the authors did not report on the average age of the most recent child at the time of recruitment, or provide any details of the number of women in the sample who were over 12 month postnatal, after which it is typically not considered the postnatal period. Intervention group women were asked to identify five behaviors they associated with being a good mum, as well as to focus on strengths and completed questions which were designed to promote positive perceptions of them as mothers. The other self-help intervention (26) asked women to write about their thoughts and emotions related to their childbirth experience. Women were randomized 96 hours post-delivery to either write about their emotions or to write about the events leading up to childbirth, childbirth and after childbirth in behavioral terms. A follow-up occurred at 3 months postnatal with psychological measures being taken. However, women were not asked to provide feedback on acceptability of the self-help task, despite the fact that the 
1 intervention was implemented in the very early postnatal period when women are often

2 occupied with the transition to motherhood.

3

4 Perez-Blasco et al (2013) [22] also found that a mindfulness based intervention resulted in a 5 significant difference from pre- to post-intervention for measures on anxiety, stress and 6 psychological distress. Women were recruited postnatally (mean 10.75 months), self7 selecting into the study in responding to a study advertisement. The intervention arm 8 received 2 hours of mindfulness based input for 8 weeks. The control group received no 9 additional input during the study period, but was also able to access 2 sessions of 10 mindfulness following completion of the post-intervention measures. Sample size was very small ( $n=26$ across both arms), and there were high rates of attrition in the control group, which may be due to the fact that they received no additional attention during the course of the trial. Additionally, it is not clear if the study focused on a universal or selected sample, there is limited information provided regarding eligibility and exclusion criteria.

Gao et al (2015) [24] examined the utility of a one-hour interpersonal therapy (IPT) based education session whilst an inpatient on the postnatal ward, coupled with a leaflet on available assistance for the postnatal period and a follow up phone call at 2 weeks postnatal, compared to just receiving the leaflet with information regarding local services. Undertaken in China, the study had a moderate sample size of 180 participants ( $n=90$ intervention and $n=90$ control), all of whom were primiparous. Results demonstrated a statistically significant group effect with women in the intervention group scoring lower for depressive symptoms on the Edinburgh Postnatal Depression Scale. Intervention group participants also scored higher on the Perceived Social Support Scale and the Parenting Sense of Competence Scale-Efficacy subscale, indicating higher perceived social support and maternal competency, respectively. No information was provided on whether staff and participants found the intervention acceptable in terms of content and process.

In summary, the studies reviewed do not provide sufficient evidence to support the use of any one intervention in the postnatal period. However, all four trials with significant differences between groups post intervention utilized a psychotherapy based approach $[21,23,24,25]$. Therefore, there would be some utility in further investigation of psychotherapy based interventions. Only one of the four studies to report significant improvement in postnatal mood actually asked participants about acceptability of the intervention [24]. Even interventions with the most significant improvement to postnatal mood scores will not be integrated successfully into routine care if they are not deemed acceptable to women, and therefore further studies should aim to include acceptability as an outcome in all instances.

\section{Discussion}


1 Continuing the theme of the findings of Morrell et al [13], no specific intervention approach

2 was strongly supported for the prevention of postnatal depression or anxiety in a universal

3 sample from this additional set of studies. For antenatal interventions, the use of both REBT

4 and education based on health locus of control appear to improve depression in the short

5 term for universal samples of women, and REBT continues to show a maintenance effect for

6 both anxiety and negative emotionality at 3 months postnatal. The literature suggests that

7 interventions conducted during the antenatal period to prevent postnatal depression

8 appear to be most effective within a selective sample with social risk factors or an indicated sample of women who have higher rates for depression but remain below the clinical threshold for diagnosis. This supports the findings of Morrell et al, who also report that parenting education and peer support appear to have good outcomes with selective and indicated samples respectively. Postnatal trials have shown varied results, with statistically significant differences in depression scores for self-help interventions, mindfulness interventions and IPT based education. A number of limitations marked the postnatal trials, including small sample size. Small sample sizes are potentially a problem particularly for prevention studies as it may be necessary to detect what are likely to be small effect sizes. Where there are no group differences it may be unclear whether the prevention strategy is ineffective or there is an absence of power to detect such differences. In addition, studies showed high attrition and poor adherence to the interventions delivered. It is often unclear why women did not adhere to the intervention as suggested or reasons for attrition as no information is provided. These issues merit investigation in their own right as uptake and motivational issues are of critical importance of the utility of any provision. The questions that arise include whether women found the content of the intervention unacceptable or unappealing and/or whether the timing of the provision was inconvenient or the time commitment too demanding. This lack of information makes it difficult to contextualize findings. It may be that acceptability needs more thorough qualitative exploration before larger trials are developed. Additionally, providing rigorous evidence that a study intervention has prevented the onset of a condition is difficult due to the uncertain nature of such disorders, although the use of RCT designs should address this through the inclusion of control groups. However, where there is high attrition and non-adherence to proposed interventions there is the potential for this design, and therefore the conclusions of the trial, to be compromised.

\section{Limitations}

A limitation of this review is the restriction to papers published in English. In addition, it has excluded biological interventions and solely focused on randomized controlled trials, which whilst viewed as a gold standard approach have their own limitations in terms of the representativeness of the samples included. Also, quality evaluations and risk of bias ratings were completed by a single author.

\section{Conclusions}


1 This literature review provides an update of published literature on interventions using a

2 trial design to prevent the onset of postnatal depression and anxiety since the publication of

3 Morrell et al's 2016 review. A total of 12 papers were identified for inclusion for this review.

4 Five papers presented interventions carried out during the antenatal period and seven

5 delivered during the postnatal period. Sample size, population and intervention method

6 differed between the trials. Based on the evidence presented in these published papers and

7 in support of the findings of Morrell et al [13], more research needs to be conducted with

8 larger samples. However, a key element is to provide good exploration of the acceptability

9 of interventions and consider how to better tailor to women's needs. The inclusion of more

10 detailed qualitative feedback of those disengaging could address this. Anxiety and other common postnatal mental health conditions were often included as primary outcomes; however, the continued emphasis on depression as a primary measure of mental health appears to remain for interventions across the perinatal period. As awareness of the impact of perinatal anxiety continues to grow, there is a need for further research to focus on the prevention of anxiety in its own right.

\section{Declaration of interest}

No conflict of interest

\section{Funding}

This research is part-funded by The National Institute for Health Research Collaboration for Leadership in Applied Health Research and Care North West Coast (NIHR CLAHRC NWC). The views expressed here are those of the author(s) and not necessarily those of the NHS, the NIHR, or the Department of Health and Social Care."

\section{References}

1] Albright, M. B. And Tamis-Lemonda, C. S (2002). Maternal Depressive Symptoms In Relation To Dimensions Of Parenting In Low-Income Mothers. Applied Developmental Science. 6(1), 24-34.

2] Acheson, D. (1998). Independent Inquiry Into Inequalities In Health. London.

3] Grigoriadis, S., Et Al. (2013). The Impact Of Maternal Depression During Pregnancy On 
1 5] Marmot, M. G. (2010). Fair Society, Healthy Lives: The Marmot Review : Strategic Review

2 Of Health Inequalities In England Post-2010. London.

3 6] Knight $M$, Nair M, Tuffnell D, Kenyon S, Shakespeare J, Brocklehurst $P$, Kurinczuk Jj (Eds.)

4 On Behalf Of Mbrrace-Uk. Saving Lives, Improving Mothers' Care - Surveillance Of Maternal

5 Deaths In The Uk 2012-14 And Lessons Learned To Inform Maternity Care From The UK And 6 Ireland Confidential Enquiries Into Maternal Deaths And Morbidity 2009-14. Oxford:

7 National Perinatal Epidemiology Unit, University Of Oxford 2016.

8 7] United Nations. (2015). Millennium Development Goals Report 2015. [Place Of Publication 9 Not Identified], United Nations Pubns.

8] United Nations. (2008). The Millennium Development Goals Report 2008. New York, United Nations. Http://

mdgs.Un.Org/Unsd/Mdg/Resources/Static/Products/Progress2008/Mdg_Report_2008_

9] Hm Government (2011). No Health Without Mental Health: A Cross-Government Mental Health Outcomes Strategy For People Of All Ages.

Https://Www.Gov.Uk/Government/Uploads/System/Uploads/Attachment_Data/File/21376 1/Dh_124058.Pdf

[10] Department of Health (2014) Closing the gap: Priorities for Essential Change in Mental Health

https://assets.publishing.service.gov.uk/government/uploads/system/uploads/attachment data/file/281250/Closing_the_gap_V2_-17_Feb_2014.pdf

11] Royal College Of Obstetricians And Gynaecologists (2011). Management Of Women With Mental Health Issues During Pregnancy And The Postnatal Period. London.

Https://Www.Rcog.Org.Uk/Globalassets/Documents/Guidelines/Managementwomenmenta Ihealthgoodpractice14.Pdf

12] National Collaborating Centre For Mental Health (Great Britain), British Psychological Society, Royal College Of Psychiatrists, \& National Institute For Health And Care Excellence (Great Britain). (2014). Antenatal And Postnatal Mental Health: Clinical Management And Service Guidance.

13] Dennis Cl, \& Dowswell T. (2013). Psychosocial And Psychological Interventions For Preventing Postpartum Depression. The Cochrane Database Of Systematic Reviews. 2013.

14] Morrell C.J., Et Al. (2016). A Systematic Review, Evidence Synthesis And Meta-Analysis Of Quantitative And Qualitative Studies Evaluating The Clinical Effectiveness, The CostEffectiveness, Safety And Acceptability Of Interventions To Prevent Postnatal Depression. Health Technology Assessment. 20, 1-414. 
1 15] Kenyon S, Jolly K, Hemming K, Hope L, Blissett J, Dann Sa, Lilford R, \& Macarthur C. 2 (2016). Lay Support For Pregnant Women With Social Risk: A Randomised Controlled 3 Trial. Bmj Open. 6.

4 16] Moshki M, Baloochi Beydokhti T, \& Cheravi K. (2014). The Effect Of Educational 5 Intervention On Prevention Of Postpartum Depression: An Application Of Health Locus Of 6 Control. Journal Of Clinical Nursing. 23, 15-16.

7 17] Mohammadi F, Malakooti J, Babapoor J, \& Mohammad-Alizadeh-Charandabi S. (2015).

8 The Effect Of A Home-Based Exercise Intervention On Postnatal Depression And Fatigue: A

9 Randomized Controlled Trial. International Journal Of Nursing Practice. 21, 478-85.

18] Anton, R And D. David (2015). A Randomized Clinical Trial Of A New Preventive Rational Emotive And Behavioural Therapeutical Program Of Prepartum And Postpartum Emotional Distress. Journal Of Evidence-Based Psychotherapies. 15(10), 3-15.

19] Barrera Az, Wickham Re, \& Muñoz Rf. (2015). Online Prevention Of Postpartum Controlled Trial. Internet Interventions. 2, 257-265.

20] Howell Ea, Bodnar-Deren S, Balbierz A, Loudon H, Mora Pa, Zlotnick C, Wang J, \& Leventhal H. (2014). An Intervention To Reduce Postpartum Depressive Symptoms: A Randomized Controlled Trial. Archives Of Women's Mental Health. 17, 57-63.

21] Fisher J, Et Al. (2016). Gender-Informed, Psychoeducational Programme For Couples To Prevent Postnatal Common Mental Disorders Among Primiparous Women: Cluster Randomised Controlled Trial. Bmj Open. 6.

22] Perez-Blasco, J., Viguer, P., \& Rodrigo, M. F. (2013). Effects Of A Mindfulness-Based Intervention On Psychological Distress, Well-Being, And Maternal Self-Efficacy In BreastFeeding Mothers: Results Of A Pilot Study. Archives Of Women's Mental Health : Official Journal Of The Section On Women's Health Of The World Psychiatric Association. 16, 22726 236.

23] Lewis, B. A., Gjerdingen, D. K., Avery, M. D., Sirard, J. R., Guo, H., Schuver, K., \& Marcus, B. H. (2014). A Randomized Trial Examining A Physical Activity Intervention For The Prevention Of Postpartum Depression: The Healthy Mom Trial. Mental Health And Physical Activity. 7, 42-49.

31 24] Gao LI, Xie W, Yang X, \& Chan Sw. (2015). Effects Of An Interpersonal-Psychotherapy32 Oriented Postnatal Programme For Chinese First-Time Mothers: A Randomized Controlled 33 Trial. International Journal Of Nursing Studies. 52, 22-9. 
1 25] Ayers S, Fitzgerald G, \& Thompson S. (2015). Brief Online Self-Help Exercises For

2 Postnatal Women To Improve Mood: A Pilot Study. Maternal And Child Health Journal. 19,

$3 \quad 2375-83$.

4 26] Di Blasio P, Miragoli S, Camisasca E, Di Vita Am, Pizzo R, \& Pipitone L. (2015). Emotional

5 Distress Following Childbirth: An Intervention To Buffer Depressive And Ptsd

6 Symptoms. Europe's Journal Of Psychology. 11, 214-32.

7 27] Slade $P$, Morrell Cj, Rigby A, Ricci K, Spittlehouse J, \& Brugha Ts. (2010). Postnatal

8 Women's Experiences Of Management Of Depressive Symptoms: A Qualitative Study. The

9 British Journal of General Practice : The Journal of The Royal College of General

10 Practitioners. 60, 440-8.

11 28] Fairbrother $N$, Janssen $P$, Antony $M$, Tucker $E$, \& Young $A$ (2016) Perinatal anxiety

12 disorder prevalence and incidence. Journal of Affective Disorders. 200, 148-155.

13 [29] World Health Organisation (2004) Prevention of mental disorders:Effective interventions

14 and policy options - a summary report.

15 http://www.who.int/mental_health/evidence/en/prevention_of_mental_disorders_sr.pdf

16 [30] Bauer A., Parsonage M., Knapp M., lemmi V. \& Adelaja B. (2014) The cost of perinatal 17 mental health problems. London: Centre for Mental Health.

18 [31] Higgins, J. P. T., Altman, D. G., Sterne, J. A. C. (ed) (2011) Chapter 8: Assessing risk of bias in 19 included studies. In: Higgins, JPT, Green S (editors). Cochrane Handbook for Systematic Reviews of 20 Interventions Version 5.1.0 (updated March 2011). The Cochrane Collaboration, 2011. Available from 21 www.handbook.cochrane.org. 